\title{
The relation between university education management and the vocational development
}

\author{
${ }^{1}$ Bakhtiar Aubaid Sharif, ${ }^{2}$ Hos hiar Marouf Kaka Mala, ${ }^{3}$ Noor Azman Ali \\ ${ }^{1}$ Technical Administration Department, Technical College of Administration, Sulaimani Polytechnic University \\ ${ }^{2}$ The Centre for Scientific Research and Strategic Studies, Lebanese French University \\ ${ }^{3}$ Department of Management and Marketing, Faculty of Economics and Management , University Putra Malay sia
}

\section{Article Info}

Received: October, 2019

Revised:October,2019

Accepted:November,2019

\section{Keywords}

University Education Management, Leadership of University Management, Vocational Development..

Corresponding Author

Bakhtiar.sharif@spu.edu.iq

\begin{abstract}
This study aims to identify the relation between the university education management and vocational development, using the analytical descriptive method based on data on vocational development.

The research also aims to measure the relationship between the university education management and vocational development and their dimensions from the point of view of university leaders and teachers in polytechnic universities in the Kurdistan Region of Iraq. To achieve the goal designed a questionnaire consisting of (31) paragraph to collect data on the field side, where 500 questionnaires were distributed to university leaders and lecturers at polytechnic universities in (Erbil, Sulaimani, Dohuk). 452 questionnaires were returned for analy sis. The most important conclusions were that the existence of a positive moral relationship between the university education management and vocational development in polytechnic universities in the Kurdistan Region of Iraq. Accordingly the researchers made a number of recommendations, the most important is need to work to improve the university performance of polytechnic universities of the Kurdistan region of Iraq by making practical use of variables that directly or indirectly affect the vocational development.
\end{abstract}

\section{Introduction}

Strategic management is an analysis of the important and salient issues of an organization that is adopted by senior managers of the organization on behalf of the owners in order to control the resources outside the organization. Given the already accelerated environmental changes and the complexity of organizational decisions, the need for a comprehensive plan to deal with such is sues becomes more evident than in the past. Strategic management, (relying on a dynamic, forward-looking, holistic and contingent mindset) is the solution to many of today's organizational problems. The basics of university education management are based on the understanding that managers of competing universities, job markets, challenges, law and regulations, governments, national customers, and customers around the world, are the determinants of today's business success. So one of the most important tools that organizations can use to succeed in the future will be "strategic management". University education management enables the organization to act in a creative and innovative way and not passively to shape its future. This style of management enables the organization to take the 
initiative and engage in activities that influence and shape its destiny, control the future, and promote vocational development. The definition of vocational development has changed over the past 10 years. Guskey (2000) defined the term as, "those processes and activities designed to enhance the professional knowledge, skills, and attitudes of educators so that they might, in turn, improve the learning of students" (p. 16). A year later, Learning Forward (2001) issued its definition that stated that vocational development was a "means by which educators acquire or enhance knowledge, skills, attitudes, and beliefs necessary to create high levels of learning for all students" (p. 2). While many models of vocational development have been researched and supported across all occupational areas as effective methods to improve student achievement, Learning Forward redefined the term for educators in 2009.

\section{Problem Statement}

Around the world, higher education systems and universities find themselves hard-pressed to adapt to changing these environment. At one end of the spectrum, rising participation and the spiraling cost of higher education force university leaders to come up with new ways to become both more effective and efficient in teaching and learning.

At the other end, the growing worldwide competition for students, researchers and national excellence initiatives put pressure on higher education institutions to reimagine and sometimes reinvent themselves.

In both scenarios, higher education institution leaders need to find ways to develop a joint vision, build support for it and then lead and organize the necessary changes to make it a reality.

The problem statement requires several questions

which have to be replied throughout

the research;

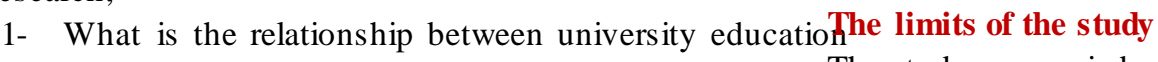

management and

vocational development?

How to use technology in vocational development to cover the requirements of the labor market?

\section{Significance of the study}

The importance of this research derives from the importance of the subject it deals with and highlights the importance of research in the following points:

1- Globalization, internationalization, higher education quality standardization, financing higher education, growth of higher education sector, academic profession development, ICT application in higher education and expansion of academic research are the driving forces behind the transformation of higher education (Altbach et al., 2009).

2- The changes of higher education institution (HEI) can be observed in the functions exerted by the HEIs, the management of the HEIs and the restructuring of the HEIs (Gumport, 2000)).

3- Qualifying and training academic staff to promote vocational development.

\section{Objectives of the study}

This study seeks to achieve the following objectives: 1-Finding the levels of importance of variables from the point of view of university education leaders and academic staff.

2-Create a correlation between the university education management and the vocational development.

3-Demonstrate the impact of university education management on vocational development.

\section{Hypotheses}

1- The levels of significance and dimensions of the main study variables vary from the point of view of the respondents in the universities.

2- There is a significant correlation of statistical significance between the University Education management and vocational development.

3- There is a direct significant impact of the university education management on the vocational development.
The study was carried out within the following limits: 6.1. Time Limits: The study is limited to the answers of university leaders and academic members in polytechnic universities in the Kurdistan Region of Iraq between October 2018 to October 2019.

6.2. Spatial limits: limited to polytechnic universities in (Erbil, Sulaimani and Dohuk). 


\section{Background of the study}

The most important research done in this section is outlined;

A study title "The concept of the university as learning organization: Its functions, techniques and possible ways of making it effective" reported that Learning organization is a concept that is becoming an increasingly widespread philosophy in our contemporary society. It has a strong humanistic orientation, being a place where people continually expand their capacity to produce results they truly desire, where new and expansive patterns of thinking are nurtured and where people are continually learning how to learn together. In order to implement learning organization techniques, universities tackle some disciplines which are essential to a learning organization. Such techniques are team learning, shared vision and systematic thinking. As a result, the paper is confined to how universities are committed to creating continuous learning opportunities, encouraging collaboration and team learning, establishing systems to capture and share learning, and connecting the university organization to its environment. It also proposed the need for a radical rethinking of the core functions of the university (Nakpodia, 2009) .

In study titled "Organizational Visioning: An Integrative Review" develop an integrated discussion of organizational vision, including a range of factors, from the reasons for visioning to the impacts of vision on individuals, groups, and organizations. The goal is to help integrate the field and to provide direction for both future research and leadership practice. Building on prior reviews, we update the literature and contrast group visioning processes with leader driven vision development. The article offers a comprehensive look at vision development, implementation, and the impact of visioning and suggests a number of propositions for future research (O’Connell, 2011).

In a study title "Strategic Planning in Institutions of Higher Education: A Case Study of Sakarya University" studied strategic planning in Sakarya University. They reported that A participatory and transparent management understanding, the effective and efficient use of resources, performance-based assessment and budgeting as well as the rapid developments experienced in informatics and communication technologies have obliged institutions of higher education to prepare their strategic plans both due to a legal obligation (Law No. 5018) and in order to realize their institutional transformation (Nermin Akyel, 2012).

The subject Learning strategies and styles in vocational education. As a result, the success of Hungarian public education, as shown by PISA research, lags far behind its possibilities. In our present paper the adaptive model of vocational education is outlined first, where teaching and learning strategies appear as regulating agents with a formative influence on the educational process. The preferred patterns of learning and teaching strategies typical of the individual yield the learning and teaching styles. In the second part of the paper, the results of a longitudinal examination performed among secondary vocational school students in Budapest are presented. The answers to the following questions are sought: how much learning strategy and style can be regarded as an individual characteristic, how it changes with the progress of studies, and whether it shows any correlation with the gender or specialization of the students (Tóth ,2012).

\section{Methodology and Data Analysis}

The researchers will depend on the scientific methods in order to ensure the research goals through the following:

-Arranging the research structure to cover the theoretical and the applied sides of the research.

-Depending on a modern model which shows the independent and the dependent variables (figure 1), which is to cover the theoretical and the applied sides of the research?

\section{The theoretical side:}

The researchers relied on getting the required data not counter the theoretical aspect of the research on Descriptive method, by reviewing the literature of the subject of books, studies, research, scientific periodicals, letters and access to the theses as well as relevant theses on the topic of research on the Internet sites to learn about the latest books on this topic.

\section{Field side:}

The data of the research field were collected and analyzed based on a questionnaire, which is the main means for diagnosing and measuring the main variables and their dimensions. 
The questionnaire form consists of

1.Personal information of members of the research community.

2.Contains paragraphs on the dimensions of the independent variable (University Education Management) and includes 16 questions.

3.Contains paragraphs on the dimensions of the dependent variable (Vocational Development) and includes 19 questions.

\section{Preparation of the Data for Analysis}

The main purpose of this section is to prepare sample data for further analysis. It included cleaning and screening of the sample data. Details of the procedures used to getting the sample data ready which analysis are explained in the following sections: coding and data entry and missing data.

\subsubsection{Coding of Variables, Dimensions and Items}

Coding is a process used to clarify the translation of respondent information and question responses to specific categories for the analysis procedures (Kerlinger \& Lee, 2000). Therefore, the coding of variables, dimensions and items is shown in the table (1).

\subsubsection{Missing Data}

Missing data refers to the fact that not all respondents answered each question in the questionnaire survey. This occurred for many reasons; they did not understand the question, did not know the right answer for the question, or were not willing to answer the question (Sekaran \& Bougie, 2016). Therefore, the missing data is a familiar problem in surveys (Hair et al., 2017). On the other hand, it is very crucial to use AMOS (Statistics Solutions) because the statistical analys is techniques of the data will not run if there is any missing data (Schumacker \& Lomax, 2004). Therefore, returned questionnaires are checked for completeness and consistency. Besides, using a missing value analysis provided by SPSS v24, it was not found any missing value.

\section{Preliminary Analysis}

This section provides the preliminary analysis of the 452 questionnaires that were collected from leaders and lecturers working in the polytechnic universities of the Kurdistan region of Iraq. In order to determine the suitability of sample data, further analysis was discovered in the treatment of response rate and background of the respondents.

\section{Response Rate}

Response refers to the number of respondents who answered the survey which is divided into the number of respondents in the sample size (Hamilton, 2009). Of the 500 questionnaires randomly distributed among leaders and lecturers of the polytechnic universities of the Kurdistan region of Iraq, only 452 questionnaires were returned for a response rate of $90 \%$. In this regard, Babbie (2007) has argued that a response rate of $50 \%$ is acceptable for surveys in social research. Thus, the response rate for the current study is more than adequate. Further, the total number of usable questionnaires was considered sufficient to run all the statistical analys is techniques, particularly a structural equation models (SEM) analysis (Hair et al., 2017).

\section{Background of the Respondents}

The respondents' demographic factors were gathered to collect information about each respondent that participated in the survey. Respondents were asked to provide information on age, gender, marital status, educational level, duration of employment, and position. The questions were designed for the respondents to choose their answers based on categories as opposed to providing specific information. Table (3) shows the profile of the respondents' demographic factors using SPSS v24.

\section{Underlying Statistical Assumptions}

Using the underlying statistical assumptions that include: normality, multicollinearity, linearity, and homoscedasticity, it can be useful for multivariate analysis. It is helpful to accommodate multiple variables in an attempt to identify and understand the complex relationship between them (Hair et al., 2017). Hence, the researchers will explain the assumptions of normality, multicollinearity, and homoscedasticity in the present section using 452 usable questionnaires.

\section{Normality Assumptions}

Normality refers to the bell-shaped curve of the data distribution for an individual metric variable and its correspondence to a normal distribution (Hair et al., 2017). A normality distribution of sample data is depicted as a symmetrical bell-shaped curve that has the highest range of frequency in the middle with smaller range of frequencies towards the extremes (Gravetter \& Wallnau, 2000). 
Skewness and Kurtosis are the main tests that can be used to validate normality assumptions (Pallant, 2007). Skewness refers to the measure of normality assumptions by describing the balance of the sample data distribution, that is, is it unbalanced and shifted to right, left or centered side and symmetrical with about the same shape on both sides, while the Kurtosis refers to the measure of normality assumptions by comparing them with a "peakedness" or "flatness" of the sample data distribution (Hair et al., 2017). As conservative rule of thumb, (Hair et al., 2017) have argued that sample data is considered normal if the test of Skewness values and test of Kurtosis values are between \pm 1.96 . Based on using SPSS v24, all of the Skewness and Kurtosis ratios are between the normal distribution \pm 1.96 , which indicated that their distribution was normal as shown in Table (4) Consequently, the assumption of normality is met.

\section{Testing Goodness of the Measurement Instrument}

All of the items that are used to measure the variables have been adapted from prior studies. Even though the borrowed measurement instrument has been confirmed of its stability and consistency, it is necessary to re-examine the exactness of the measurement instruments because the previous studies were done in different business environment and organizational culture. According to Sekaran \& Bougie (2016), the goodness of measurement instrument is used to ensure they are stability, consistency, and accuracy between items of each variable. Any researcher can examine the goodness of measurement instrument through the Exploratory Factor Analysis (EFA), Confirmatory Factor Analysis (CFA), reliability, and construct validity. Hence, they were established, as described below.

Dimensionality of the measurement instrument using exploratory factor analysis before further tests were performed, the construct was subjected to validity and reliability tests. Factor analys is was carried out to test the construct of the questionnaires. Basically the purpose is "to identify small number of themes, dimensions, components or factors underlying a relatively large set of variables" (Meyers, et al., 2006, p. 465).

Exploratory Factor Analysis (EFA) is an interdependence technique which primary purpose is to define the underlying structure among the variables in the analysis (Hair et al., 2017). Then, EFA is a useful tool for understanding the factor structure of a measure instrument and to confirm that the items are suitable for each variable. It is extremely helpful for the primary purpose in the development of a set of measurement items as all factor loadings are free to vary across groups (Dobni, 2008; Hair et al., 2017).

In determining the factorability of the dimensions, the Bartlett's test of sphericity had to be significant and the Kaiser-Meyer-Olkin (KMO) measure of sampling adequacy had to be more than 0.50 in order to be acceptable. Moreover, Bartlett's test shows the correlation matrix among the items. Some authors suggested 0.6 and above as mediocre, 0.5 and above as miserable and below 0.5 as not acceptable (Hair et al., 2017). Additionally, The criteria developed by Lgbaria et al.'s (1995) was used in the current study for cross loading, that is, a given item should load 0.50 or higher on a specific factor and have a loading no higher than 0.35 on other factors. Based on above, the exploratory factor analysis of variables are interpreted as follows:

\subsection{Exploratory Factor Analysis of the University Education Management}

Based on SPSS v.24 results, the Kaiser-Meyer-Olkin (KMO) measure of sampling adequacy at 0.949 indicates that factor analys is can be conducted on the data. Moreover, Bartlett test of Sphericity was very large significant at $\mathrm{c} 2=3974.460$, with a $\mathrm{p}<.000$. The following table (5) shows the results.

The same procedure of the Varimax rotation method was conducted on the university education management. The outputs of table (6) showed all sixteen items were known as an accurate tool to measure this variable. Then it conducted to determine which items should group to form dimensions. They were grouped in four dimensions. The final factor analysis was conducted on the remaining all items.

\subsection{Exploratory Factor Analysis of the Vocational Development}

Based on SPSS v.24 results, the Kaiser-Meyer-Olkin (KMO) measure of sampling adequacy at 0.958 indicates that factor analys is can be conducted on the data. Moreover, Bartlett test of Sphericity was very 
large significant at $\mathrm{c} 2=6515.268$, with a $\mathrm{p}<.000$. The following Table (7) shows the results.

In the context of Varimax rotation method, the outputs of Table (8) displays that all nineteen items were known as an accurate tool to measure this variable. Then conducted to determine which items should group to form dimensions. They were grouped in three dimensions. Additionally, four items (RVD5, RVD7, MVS1 and MVS6) were deleted due to cross loading. The criteria developed by Lgbaria et al.'s (1995) was used in the current study for cross loading, that is, a given item should load 0.50 or higher on a specific factor. The final factor analysis was conducted on the remaining fifteen items.

\section{Reliability of the Measurement Instrument}

Reliability is the degree to which measures are free from error and therefore yield consistent results (Zikmund, 2003). Additionally, reliability test was conducted to determine the stability and consistency of an instrument in measuring a concept to a degree that the observed score has minimal error. Cronbach's alpha coefficient is adequate to estimate the reliability of the measurement instrument (Hair et al., 2017). According to Sekaran \& Bougie (2016), Cronbach's alpha can be considered a perfectly adequate index of the interim consistency reliability. Reliability which is less than 0.6 is consider poor, reliability test value that is in the range of 0.7 is considered acceptable, those more than 0.8 to 0.9 are considered very good and the closer the Cronbach's Alpha is to 1 , the higher the internal consistency. Therefore, a Cronbach alpha value of .70 is considered the cut-off value. Table (9) displays the reliability test results of the measurement instrument using SPSS v24.

As shown in table (9), the results of the Cronbach's alpha values exceeded the required level of .70 . These results suggest that the theoretical variables display a good internal stability and consistency.

\section{Descriptive Statistics of the Variables}

The descriptive statistics of the variables through mean, standard error, standard deviation, and variance can give the researcher a detailed idea of how the participants in the survey have responded to the items in the questionnaire (Sekaran \& Bougie,
2016). The descriptive statistics using SPSS v24 of each variable can be seen as follow:

10.1. Descriptive Statistics of the University Education Management

As evidenced in the Table (10) summary of mean, standard error, standard deviation, and variance for university education management. The frequency distribution for the 16 items in the sub-scale of four dimensions shows with the mean (3.197319), standard error (0.051739), standard deviation (1.099983), and variance (1.21175). As a result, the sample data is meaningful for achieving the current study's objectives. Moreover, it is confirmed that the respondents tend to believe that strategic transformation plays its important role in determining an organizational successful.

\subsection{Descriptive Statistics of the Vocational Development}

As evidenced in the table (11) summary of mean, standard error, standard deviation, and variance for vocational development. The frequency distribution for the 15 items in the sub-scale of three dimensions shows with the mean (3.153247), standard error (0.052397), standard deviation (1.113974), and variance (1.242). As a result, the sample data is meaningful for achieving the current study's objectives. Moreover, it is confirmed that the respondents tend to believe that strategic transformation plays its important role in determining an organizational successful.

\section{Hypotheses Testing Using Structural Equation Model (SEM)}

SEM is a multivariate analysis used to test the relation between and they direct and indirect effect by estimating a series of separate, still interdependent, multiple regression equation simultaneously (Ellis \& Webster, 1998). Indeed, the main objective of SEM analysis is to determine the extent to which the proposed model for observed and latent variables is supported by sample data collection (Anderson \& Gerbing, 1988; Schumacker \& Lomax, 2004). Specifically, SEM is used to examine the covariation structure among the observed variables. In order to reduce the number of those variables into a smaller number of latent variables (Schreiber, Nora, Stage, Barlow, \& 
King, 2006), the observed variables are a set of variables that researchers use for defining or inferring the latent variable or construct (Schumacker \& Lomax, 2004). While the latent variables are known as constructs or unobserved variables, which are required two or more measured indicators (Ullman, 2006). The structural equation model using AMOS v24 at the macro level (of the all universities in one model) can be seen as follow:

\subsection{Structural Equation Model of Exogenous Variable}

The current study was performed with exogenous models and some fitness indicators in order to analyze whether relationships exist between exogenous latent variables (university education management, and vocational development). Only 31 items of overall exogenous latent variables were presented in this model. Furthermore, all these items were retained. This is because the results of CFA confirmed that the sample data had satisfactory fit to the exogenous model (GFI $=.937, \mathrm{CFI}=.965$, and RMSEA = .049). Additionally, the Chi-square index was significant $(\mathrm{c} 2=1609.062, \mathrm{df}=766, \mathrm{c} 2 / \mathrm{df}=$ 2.101). The remaining items of exogenous model were used for running the final SEM model.

As evident in table (12), all results of SRW estimations of the exogenous model showed that all the 31 items were at an appropriate level. This is because all values of SRW were above .50. Moreover, all the C.R. values were greater than 1.96 and all the 31 items loadings and structural relationships are significant at the $p>.001$ level.

Table (13) shows that the correlation relationships of the paths are statistically significant. Comparing these results with the hypotheses, the standardized path coefficient of .965 suggests that university education management has a positive and statistically significant related to vocational development use (H1).

\section{Summary of Hypotheses}

SPSS v24 and AMOS v24 were used to test the nine hypotheses proposed in the current study. The result of this analysis is used to accept or reject the hypotheses based on the significance of the standardized path coefficient of the relationships, C.R. value, $p$ value, and significant level at 05 .

In that case, the overall hypotheses testing all direct and indirect relationships, differences and as conceptualized are summarized in table (14).

\section{Conclusions and Recommendations}

\section{Conclusions}

1-This study expects that the universities' ability to achieve high level of vocational development would depend on the university education management.

2-The strength of this strategy lies in their knowledge capacities which are based on their stock of knowledge. It is expected that universities were able to achieve fully university education management. Moreover, by having these capabilities, the universities are able to identify and transform it into their vocational development.

3-The university education management could also enhance the vocational development. Universities develop their own competencies and capabilities that disallow others to imitate its progress.

4-The findings proved the influence of university education management on the vocational development .

5-The integrated variables of both university education management and vocational development are vital to the universities.

6-The result indicates that there are some problems in the university education management. Without these variables, it would be difficult for universities to move to vocational development.

7-According to opinion of respondents, there are significant differences (H3) between dependent variable and independent variables.

8-Furthermore according to opinion of respondents, there is no significant variances between the groups.

\section{Recommendations}

1-There is need to work to improve the performance of polytechnic universities of the Kurdistan region of Iraq (Sulaimani, Erbil, and Dohuk) through the adoption of strategic thinking to achieve excellence and sustainability in university performance and excellence, which universities aspire to reach by facing the impact of competitive environment factors characterized by the dynamics of the surrounding variables.

2-There is need to increase the capacity of polytechnic universities of the Kurdistan region of Iraq in Sulaimani, Erbil and Dohuk to adopt strategies in order to be able to create and exploit opportunities for achieving organizational development and leadership in its field.

3-The need to direct those in charge of the management of polytechnic universities of the Kurdistan region of Iraq (Sulaimani, Erbil, and Dohuk) to use a variety of teaching methods to increase the level of innovative and creative field of educational services. 
4-The need to seek to increase the interest of directors of polytechnic universities in Sulaimani, Erbil and Dohuk to vocational development through the proper application of the management of university education, which ensures the balance between the planned and actually achieved.

5-There is need to continuously strive to achieve the goals of polytechnic universities of the Kurdistan region of Iraq by retaining skilled and talented lecturers, who contribute to the achievement of its goals.

6-There is need for leaders of polytechnic universities (Sulaimani, Erbil, and Dohuk) to adopt mechanisms to develop their capabilities by seeking to employ workers who have the capabilities and capabilities to enable them to achieve their goals.

7-There is need to create the motivation of the polytechnic universities of the Kurdistan region of Iraq towards the use of their capabilities for the purpose of creating an organizational climate prevailing in the spirit of the working group to reduce problems that may occur while encouraging communication with leaders, lecturers, and all stakeholders.

8-There is need to work to improve the university performance of polytechnic universities of the Kurdistan region of Iraq by making practical use of variables that directly or indirectly affect the vocational development.

\section{References}

1. Adcroft, A., Willis, R. \& Hurst, J. (2008). A new model for managing change: The holistic view. The Journal of Business Strategy, 29(1): 40-45.

2. Anderson, J. C., \& Gerbing, D. W. (1988). Structural equation modeling in practice: $A$ review and recommended two-step approach. Psychological Bulletin, 103(3), 411-423.

3. Babbie, E. (2007). The Practice of Social Research (11th ed.). Belmont, CA: Wadsworth.

4. Bagozzi, R. P., \& Yi, Y. (1988). On the evaluation of structural equation models. Journal of the Academy of Marketing Science, 16(1), 74-94.

5. Chemers, M. M. (2000). Leadership research and theory: A functional integration. Group Dynamics: Theory, Research, and Practice, 4 (1), 27-43.

6. Cheng, P. H., Yang, T. H., Yang, C. H., Lin, G. H., Lai, F., Chen, C. L., Lee, H. H., Sun, Y. S., Lai, J. S., \& Chen, S. J. (2005). A collaborative knowledge management process for implementing healthcare enterprise information systems. IEEE Xplore, 604608.

7. Christian Kingombe, (2011). " Lessons for Developing Countries from Experience with
Technical and Vocational Education and Training ", International Growth Centre, F-39011-SLE-1.

8. Davis, E. \& Smith, W. (2005). The power of purpose: Creating transformational leadership capacity. International Leadership Association Conference, Amsterdam.

9. Dobni, C. B. (2008). Measuring innovation culture in organizations: The development of a generalized innovation culture construct using exploratory factor analysis. European Journal of Innovation Management, 11(4), 539-559.

10. Gravetter, F. J., \& Wallnau, L. B. (2000). Statistics for the Behavioural Sciences (5th ed.). Belmont, CA: Wadsworth.

11. Gumport, P. J. (2000). Academic restructuring: Organizational change and institutional imperatives. The International Journal of Higher Education Research, 67-91.

12. Hair, Jr. J. F., Black, W. C., Babin, B. J., \& Anderson, R. E. (2017). Multivariate data analysis: A global perspective. London: Pearson.

13. Härdle, W. K, \& Simar, L. (2015). Applied Multivariate Statistical Analysis, (4th ed.). Belmont, CA: Wadsworth.

14. Hoe, S. L. (2008). Issues and procedure in adopting structural equation modeling technique. Journal of Applied Quantitative Method, 3(1), 76-83.

15. Hooper, D., Coughlan, J., \& Mullen, M. R. (2008). Structural equation modelling: guidelines for determining model fit. Elect. J. Bus. Res. Methods, 6(1), 53-60.

16. Hu, L., \& Bentler, P. M. (1999). Cutoff criteria for fit indexes in covariance structure analysis: Conventional criteria versus new alternatives. Structural Equation Modeling, 6(1), 1-55.

17. Huang, J. (2007). Market performance analys is of the online news industry. Dissertation presented at The University of Texas at Austin.

18. Igbaria, M., Guimaraes, T. and Davis, G. B. "Testing the Determinants of Microcomputer Usage via a Structural Equation model," Journal of Management Information Systems, (11:4), Spring 1995, pp.87-114.

19. Kerlinger, F. N., \& Lee, H. B. (2000). Foundations of behavioral research (4th ed.). Holt, NY: Harcourt College Publishers.

20. Kline, R. (2011). Principles and practice of structural equation modeling (3rd ed.). New York: Guilford Press.

21. Mabey, C. (2008) Management development and firm performance in Germany, Norway, Spain and the UK. Journal of International Busines s Studies, 39: 1327-1342

22. Meyers, L. S., Gamst, G., \& Guarino, A.J. (2006). Applied multivariate research: Design and interpretation. Thousand Oaks, CA: Sage. 
23. Nakpodia, E. (2009). The concept of the university as learning organization. Journal of public administration and policy research, 79-83.

24. Nermin Akyel, T. K. (2012). Strategic Planning in Institutions of Higher Education: A Case Study of Sakarya University. Procedia - Social and Behavioral Sciences, 66-72.

25. O'Connell, C. (2011). Solutions for a cultivated planet. A nature research journal , 337-342.

26. Pallant, J. (2007). SPSS survival manual: A step by step guide to data analysis using SPSS for Windows (3rd ed.). Maidenhead, England; New York: McGraw Hill/Open University Press.

27. Péter Tóth, (2012). " Learning Strategies and Styles in Vocational Education ", Acta Polytechnica Hungarica Vol. 9, No. 3.

28. Peters T.J., 1984. Strategy follows structure: developing distinctive skills. California Management Review, 26(3), pp. 111-125

29. PG Altbach, L. R. (2009). Trends in global higher education: Tracking an academic revolution. UNESCO 2009 World Conference on Higher Education, 6.

30. Raykov, T., \& Marcoulides, G. A. (2000). A method for comparing completely standardized solutions in multiple groups. Structural Equation Modeling, 7, 292-308.

31. Schreiber, J. B., Nora, A., Stage, F. K., Barlow, E. A., \& King, J. (2006). Reporting structural equation modeling and confirmatory factor analysis results: A review. The Journal of Educational Research, 99(6), 323-337.

32. Schumacker, R. E., \& Lomax, R. G. (2004). A beginner's guide to structural equation modeling (2nd ed.). Lawrence Erlbaum Associates, Inc., Mahwah, NJ.

33. Scott, P. (2011). Leadership in universities. The International Journal of Leadership in Public Services, 7 (3), 229-234.

34. Sekaran, U., \& Bougie, R. (2016). Research methods for business: A skill building approach (7th ed.). UK: John Wiley \& Sons.

35. Tabachnick, B. G., \& Fidell, L. S. (2007). Using multivariate statistics (5th ed.). Boston: Allyn and Bacon.

36. Taylor, F.W. (1911) Principles of Scientific Management. New York: Harper.

37. Ullman, J. B. (2006). Structural equation modeling: Reviewing the basics and moving forward. Journal of Personality Assessment, 87(1), 35-50.

38. Webster, C. (1998). Geographically compact areas (Effects of researcher presence and appeal on response quality in hand-delivered, self-administered surveys). Mississippi State University USA. 


\section{Appendix}

\section{Questionnaire form}

\section{Kurdistan Region Government \\ Ministry of Higher Education \& Scientific Research \\ Sulaimani Polytechnic University \\ Technical college of Administration \\ Department of Technical Administration}

\section{$1^{\text {st}}$ : Identification information:}

- Age: 25-34 years $\square, 35-44$ years $\square, 45$ years and older $\square$

- Gender: Female $\square$, Male $\square$

- Marital status: single $\square$, married $\square$

- Education: Bachelor $\square$, High diploma $\square$, Master $\square, \mathrm{PhD}$ degree $\square$

- Duration of employment: under 5 years $\square, 5$-10 years $\square, 11$ - 15 years $\square$, over 15 years $\square$

- Position: Dean $\square$, Deputy Dean $\square$, Head of Department $\square$, Manager of Directorate $\square$, Head of Division $\square$, Academic Staff $\square$.

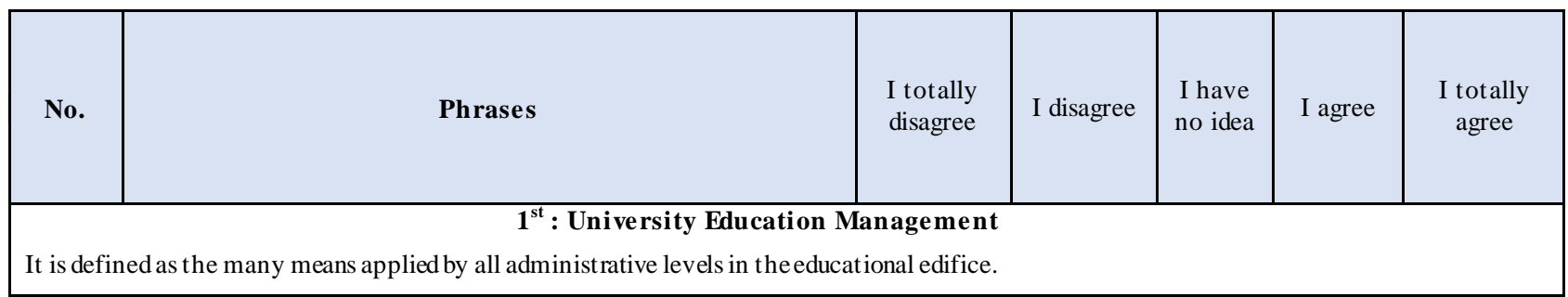

\section{1- University education planning}

It is the first and most important activity of an organization's management process, starting with set ting goals, set ting priorities, harnessing the available resources through which the desired objectives can be achieved, and achieving positive results in the management process.

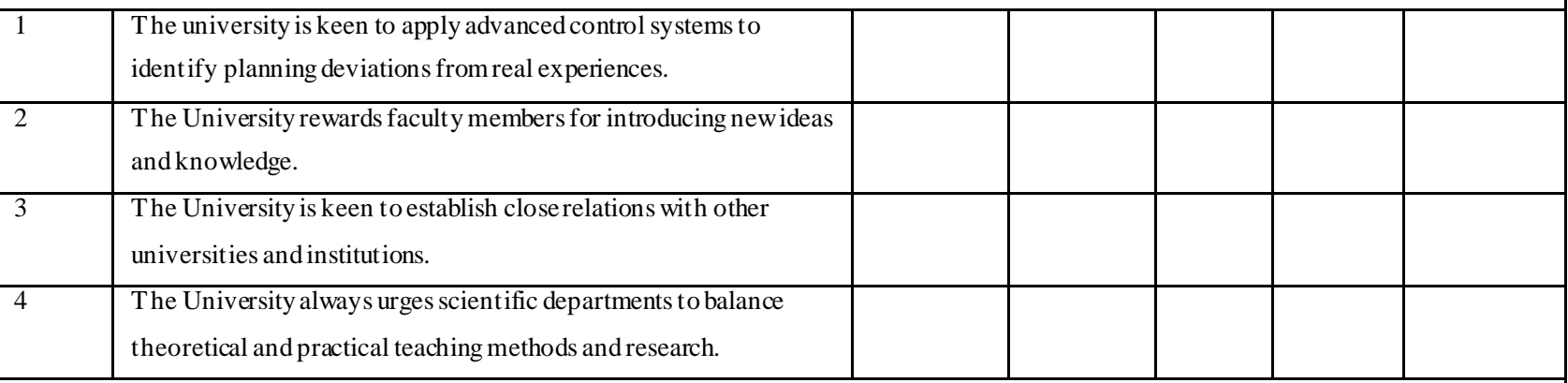

\section{2- Organization of university education}

It is a sub-process of the major administrative process in organizations working in different sectors, and is classified as one of the successive and continuous administrative support operations, and technical operations specialized in investing the resources owned by the or ganization.

\begin{tabular}{|l|l|l|l|l|l|}
\hline 5 & $\begin{array}{l}\text { The University provides appropriate reports and information to } \\
\text { stakeholders. }\end{array}$ & & & & \\
\hline 6 & $\begin{array}{l}\text { The University uses many resources to acquire and develop } \\
\text { knowledge. }\end{array}$ & & & & \\
\hline 7 & $\begin{array}{l}\text { The University has a clear policy for formal and systematic review } \\
\text { of knowledge. }\end{array}$ & & & & \\
\hline 8 & $\begin{array}{l}\text { The University holds regular conferences, seminars, meetings, } \\
\text { lectures and training sessions to share knowledge continuously. }\end{array}$ & & & & \\
\hline
\end{tabular}

3- leadership of university education 


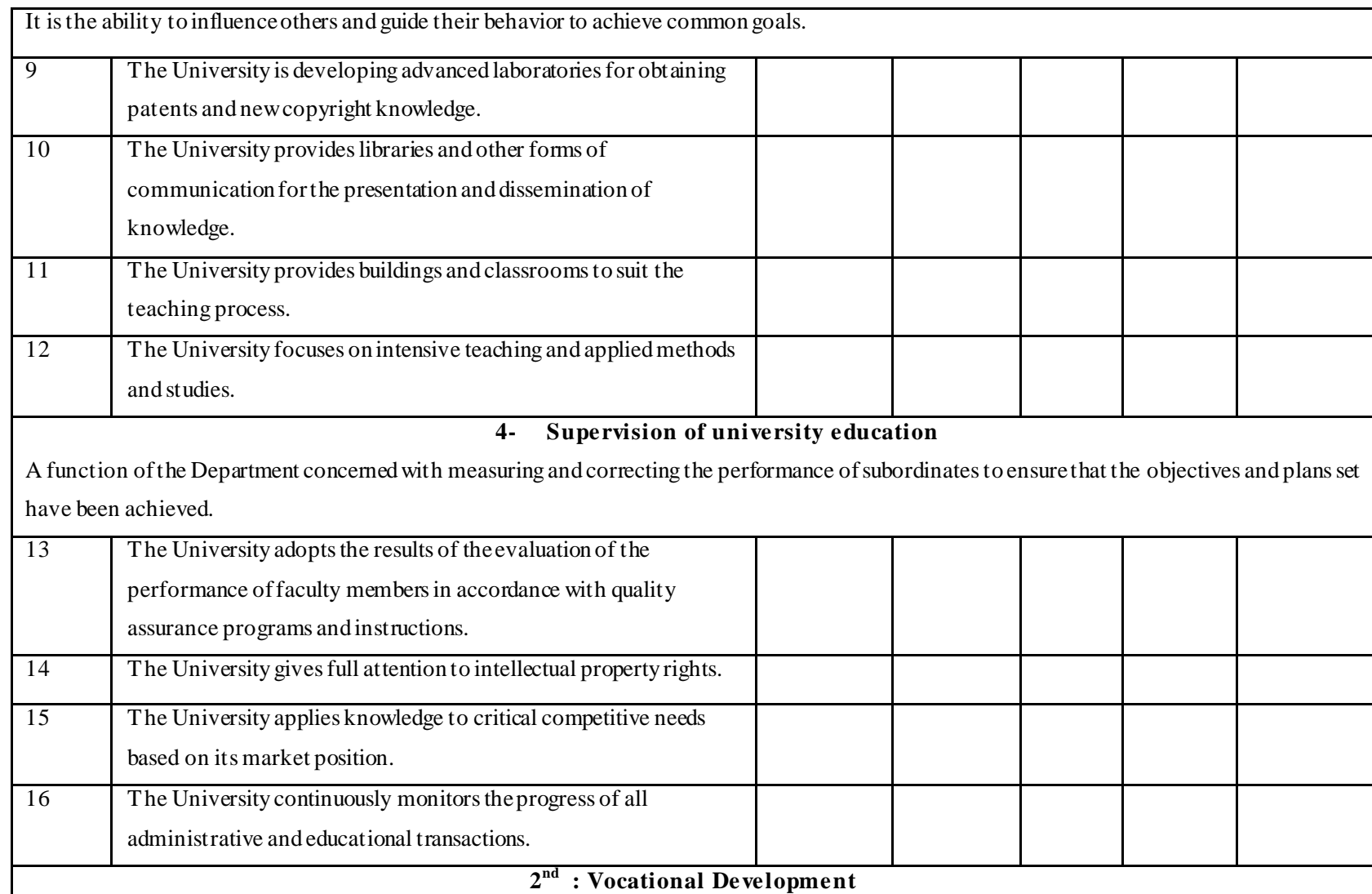

The process of the interaction of faculty members with scientific expertise and new skills in order to develop habits and at titudes, and his method of work to enable him to perform his duties and educational dut ies more efficiently while keeping up with everything new in his field.

\section{1- Scientific and technical research and development}

Research and development is one of the policies adopted by the Organization to achieve its objectives.

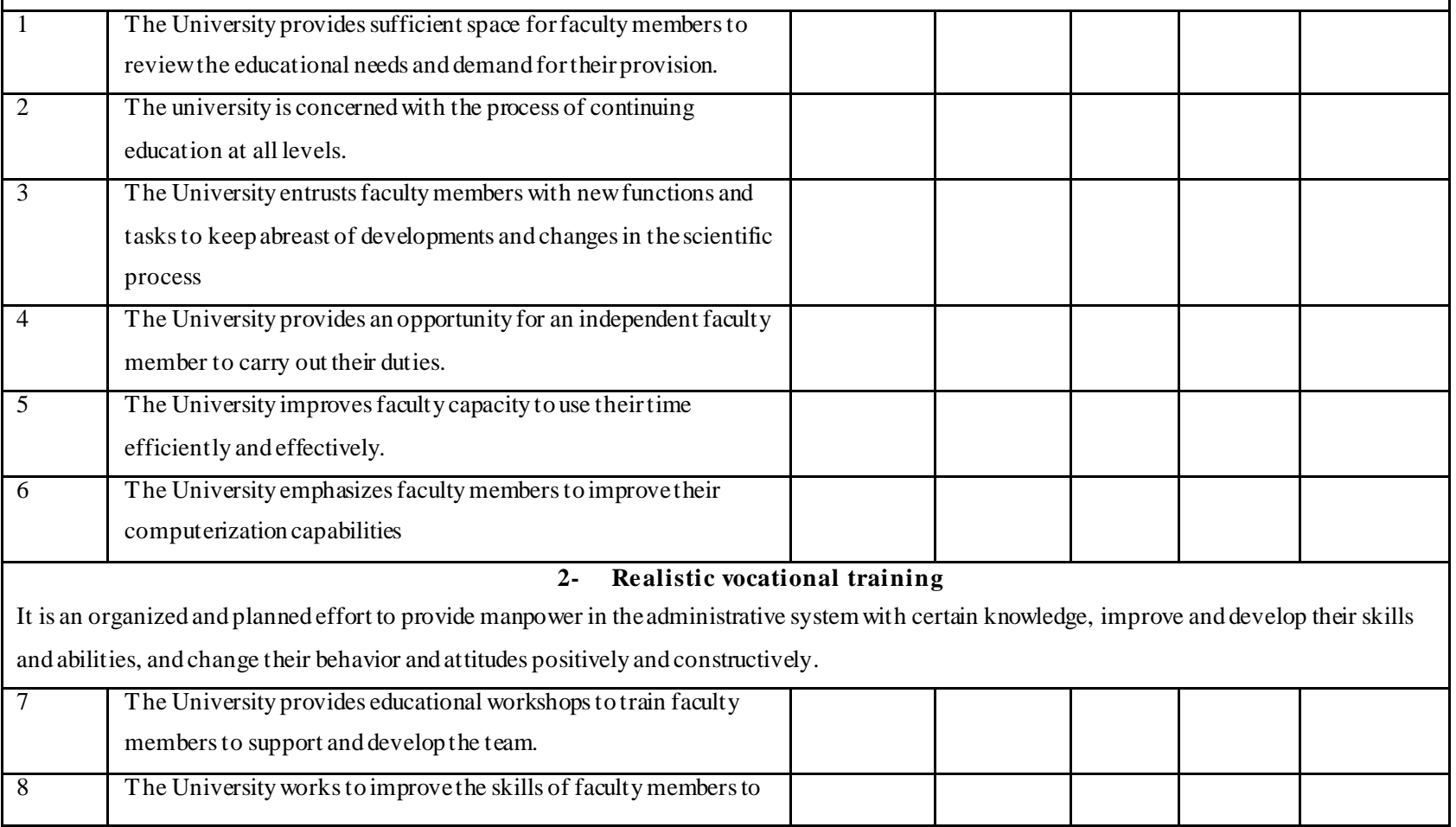




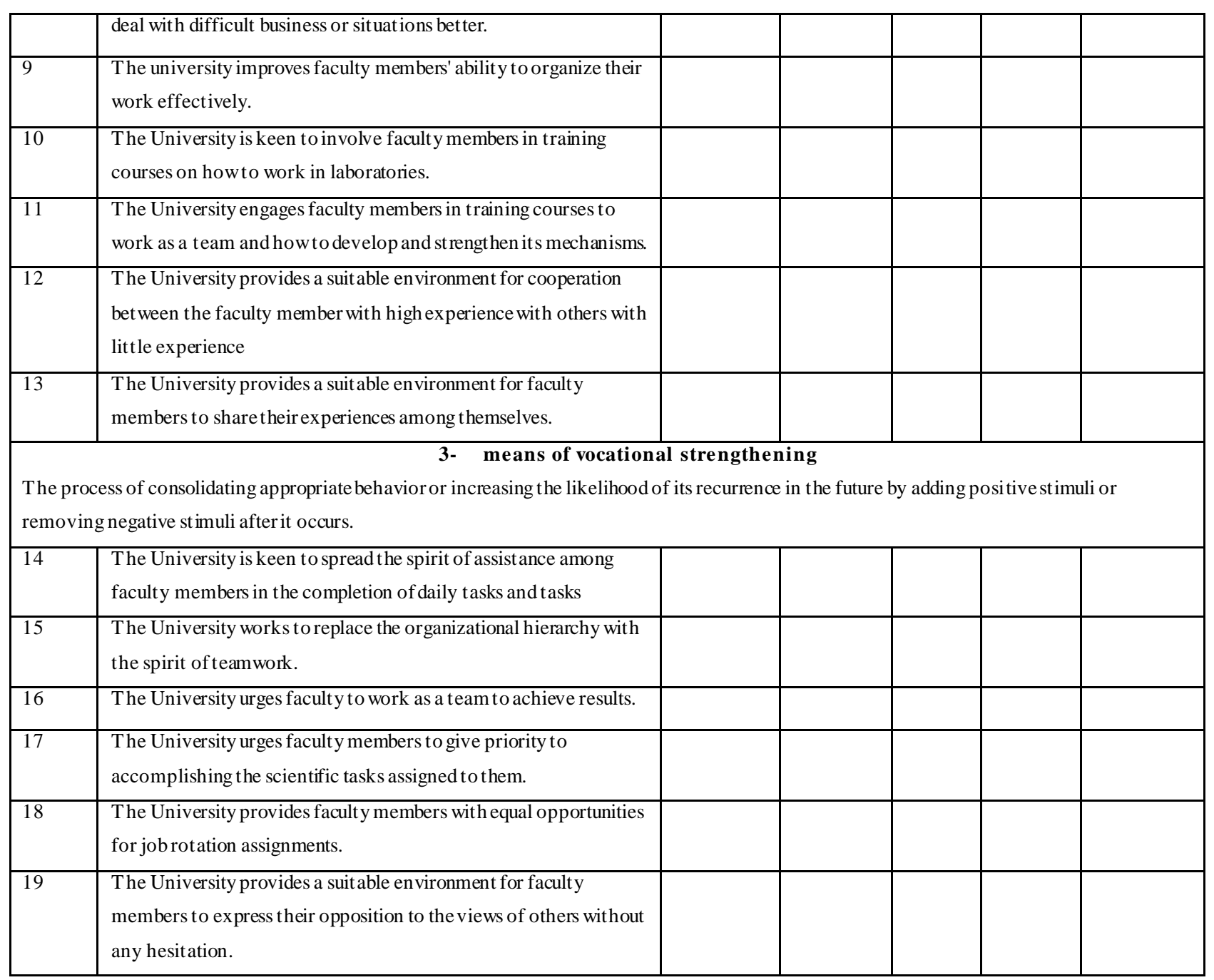




\section{University Education}

Management (UEM)

University Education Planning

Organization of University Education

Leadership of University Education

Supervision of University Education

\section{Vocational Development (VD)}

Scientific and technical research and

development

Realistic Vocational Training

Means of Vocational Strengthening

Table (1) Coding of Variables, Dimensions and Items

\begin{tabular}{|c|c|c|c|c|}
\hline Variable & Variable Code & Dimension & Dimension Code & $\begin{array}{l}\text { Numbers } \\
\text { of Items }\end{array}$ \\
\hline \multirow{4}{*}{$\begin{array}{l}\text { University Education } \\
\text { Management }\end{array}$} & \multirow{4}{*}{ UEM } & University Education Planning & UEP & 4 \\
\hline & & $\begin{array}{c}\text { Organization of University } \\
\text { Education }\end{array}$ & OUE & 4 \\
\hline & & $\begin{array}{c}\text { Leadership of University } \\
\text { Education }\end{array}$ & LUE & 4 \\
\hline & & $\begin{array}{c}\text { Supervision of University } \\
\text { Education }\end{array}$ & SUE & 4 \\
\hline \multirow{3}{*}{ Vocational Development } & \multirow{3}{*}{ VD } & $\begin{array}{l}\text { Scientific and technical } \\
\text { research and development }\end{array}$ & STRD & 6 \\
\hline & & Realistic Vocational Training & RVT & 7 \\
\hline & & $\begin{array}{l}\text { Means of Vocational } \\
\text { Strengthening }\end{array}$ & MVS & 6 \\
\hline
\end{tabular}

Prepared by Researchers 
Table (2) Summary of the Response Rate

\begin{tabular}{|l|r|r|}
\hline Questionnaires Status & Count & Percentage \\
\hline Distributed & 500 & $100 \%$ \\
\hline Not Returned & 48 & $10 \%$ \\
\hline Total Usable Questionnaires & 452 & $90 \%$ \\
\hline
\end{tabular}

Prepared by Researchers

Table (3) Profile of the Respondents' Demographic Factors

\begin{tabular}{|c|c|c|c|c|c|}
\hline \multicolumn{2}{|c|}{ Details } & Frequency & Percent & Valid Percent & $\begin{array}{l}\text { Cumulativ } \\
\text { e Percent }\end{array}$ \\
\hline \multirow{4}{*}{ Age } & $\begin{array}{l}25-34 \\
\text { years }\end{array}$ & 150 & 33.2 & 33.2 & 33.2 \\
\hline & $\begin{array}{l}35-44 \\
\text { years }\end{array}$ & 202 & 44.7 & 44.7 & 77.9 \\
\hline & $\begin{array}{l}45 \text { years } \\
\text { and older }\end{array}$ & 100 & 22.1 & 22.1 & 100.0 \\
\hline & Total & 452 & 100.0 & 100.0 & \\
\hline \multirow{3}{*}{ Gender } & Female & 164 & 36.3 & 36.3 & 36.3 \\
\hline & Male & 288 & 63.7 & 63.7 & 100.0 \\
\hline & Total & 452 & 100.0 & 100.0 & \\
\hline \multirow{3}{*}{$\begin{array}{c}\text { Marital } \\
\text { Status }\end{array}$} & Single & 102 & 22.6 & 22.6 & 22.6 \\
\hline & Married & 350 & 77.4 & 77.4 & 100.0 \\
\hline & Total & 452 & 100.0 & 100.0 & \\
\hline \multirow{5}{*}{$\begin{array}{l}\text { Educatio } \\
\text { nal Level }\end{array}$} & Bachelor & 158 & 35.0 & 35.0 & 35.0 \\
\hline & $\begin{array}{c}\text { High } \\
\text { diploma }\end{array}$ & 31 & 6.9 & 6.9 & 41.8 \\
\hline & Master & 198 & 43.8 & 43.8 & 85.6 \\
\hline & $\begin{array}{c}\text { PhD } \\
\text { degree }\end{array}$ & 65 & 14.4 & 14.4 & 100.0 \\
\hline & Total & 452 & 100.0 & 100.0 & \\
\hline \multirow{5}{*}{$\begin{array}{l}\text { Duration } \\
\text { of } \\
\text { Employ } \\
\text { ment }\end{array}$} & $\begin{array}{l}\text { Under } 5 \\
\text { years }\end{array}$ & 41 & 9.1 & 9.1 & 9.1 \\
\hline & $5-10$ years & 141 & 31.2 & 31.2 & 40.3 \\
\hline & $\begin{array}{l}11-15 \\
\text { years }\end{array}$ & 134 & 29.6 & 29.6 & 69.9 \\
\hline & $\begin{array}{c}\text { over } 15 \\
\text { years }\end{array}$ & 136 & 30.1 & 30.1 & 100.0 \\
\hline & Total & 452 & 100.0 & 100.0 & \\
\hline \multirow{7}{*}{ Position } & Dean & 10 & 2.2 & 2.2 & 2.2 \\
\hline & $\begin{array}{c}\text { Deputy } \\
\text { Dean }\end{array}$ & 9 & 2.0 & 2.0 & 4.2 \\
\hline & $\begin{array}{c}\text { Head of } \\
\text { Departme } \\
\text { nt }\end{array}$ & 55 & 12.2 & 12.2 & 16.4 \\
\hline & $\begin{array}{c}\text { Manager } \\
\text { of } \\
\text { Directorat } \\
\text { e }\end{array}$ & 50 & 11.1 & 11.1 & 27.4 \\
\hline & $\begin{array}{l}\text { Head of } \\
\text { Division }\end{array}$ & 119 & 26.3 & 26.3 & 53.8 \\
\hline & $\begin{array}{c}\text { Academic } \\
\text { Staff }\end{array}$ & 209 & 46.2 & 46.2 & 100.0 \\
\hline & Total & 452 & 100.0 & 100.0 & \\
\hline
\end{tabular}


Table (4) Skewness and Kurtosis Test of Normality Distribution $(\mathrm{n}=452)$

\begin{tabular}{|l|r|r|r|r|}
\hline \multirow{2}{*}{ Variable } & \multicolumn{2}{|c|}{ Skewness } & \multicolumn{2}{c|}{ Kurtosis } \\
\cline { 2 - 5 } & Statistic & \multicolumn{1}{c|}{ Std. Error } & Statistic & \multicolumn{1}{c|}{ Std. Error } \\
\hline UEM & $-.387-$ & .115 & $-.209-$ & .229 \\
\hline VD & $-.251-$ & .115 & $-.600-$ & .229 \\
\hline UEP & $-.543-$ & .115 & $-.182-$ & .229 \\
\hline OUE & $-.394-$ & .115 & $-.273-$ & .229 \\
\hline LUE & $-.229-$ & .115 & $-.555-$ & .229 \\
\hline SUE & $-.268-$ & .115 & $-.444-$ & .229 \\
\hline STRD & $-.288-$ & .115 & $-.609-$ & .229 \\
\hline RVD & $-.198-$ & .115 & $-.671-$ & .229 \\
\hline MVS & $-.346-$ & .115 & $-.532-$ & .229 \\
\hline
\end{tabular}

Table (5) Kaiser-Meyer-Olkin of the University Education Management ( $\mathrm{n}=452$ )

\begin{tabular}{|l|l|l|}
\hline \multirow{2}{*}{ Kaiser-Meyer-Olkin Measure of Sampling Adequacy. } & .949 \\
\hline \multirow{3}{*}{ Bartlett's Test of Sphericity } & Approx.Chi-Square & 3974.460 \\
\cline { 2 - 3 } & $\mathrm{df}$ & 120 \\
\cline { 2 - 3 } & Sig. & .000 \\
\hline
\end{tabular}

Table (6) Exploratory Factor Loadings of the University Education Management ( $\mathrm{n}=452)$

\begin{tabular}{|c|c|c|c|c|}
\hline \multirow{2}{*}{ Item } & \multicolumn{5}{|c|}{ Component } \\
\hline & 1 & 2 & 3 & 4 \\
\hline UEP1 & & .559 & & \\
\hline UEP2 & & .676 & & \\
\hline UEP3 & & .824 & & \\
\hline UEP4 & & .574 & & .721 \\
\hline OUE1 & & & & .749 \\
\hline OUE2 & & & & .617 \\
\hline OUE3 & & & & \\
\hline OUE4 & & & .659 & \\
\hline LUE1 & & & & \\
\hline LUE2 & & & & \\
\hline LUE3 & & & & \\
\hline LUE4 & & & & \\
\hline SUE1 & .734 & & & \\
\hline SUE2 & .734 & & & \\
\hline SUE3 & .748 & & & \\
\hline SUE4 & .679 & & & \\
\hline
\end{tabular}


Table (7) Kaiser-Meyer-Olkin of the Vocational Development ( $\mathrm{n}=452$ )

\begin{tabular}{|l|l|l|}
\hline \multirow{2}{*}{ Kaiser-Meyer-Olkin Measure of Sampling Adequacy. } & .958 \\
\hline \multirow{3}{*}{ Bartlett's Test of Sphericity } & Approx.Chi-Square & 6515.268 \\
\cline { 2 - 3 } & $\mathrm{df}$ & 171 \\
\cline { 2 - 3 } & Sig. & .000 \\
\hline
\end{tabular}

Table (8) Exploratory Factor Loadings of Vocational Development ( $\mathrm{n}=452)$

\begin{tabular}{|l|l|l|l|}
\hline \multirow{2}{*}{ Item } & \multicolumn{3}{|c|}{ Component } \\
\cline { 2 - 4 } & 1 & 2 & 3 \\
\hline STRD1 & .722 & & \\
\hline STRD2 & .726 & & \\
\hline STRD3 & .649 & & \\
\hline STRD4 & .712 & & \\
\hline STRD5 & .699 & & .614 \\
\hline STRD6 & .644 & & .562 \\
\hline RVD1 & .508 & & .604 \\
\hline RVD2 & .546 & & .771 \\
\hline RVD3 & & & .640 \\
\hline RVD4 & & & .599 \\
\hline RVD5 & & .415 & \\
\hline RVD6 & & .429 & \\
\hline RVD7 & .505 & .673 & \\
\hline MVS1 & & .744 & \\
\hline MVS2 & & .736 & \\
\hline MVS3 & & .738 & \\
\hline MVS4 & & .726 & \\
\hline MVS5 & & .694 & \\
\hline MVS6 & & & \\
\hline
\end{tabular}

Table (9) Reliability Test Results of the Measurement Instrument ( $\mathrm{n}=452)$

\begin{tabular}{|c|c|c|r|}
\hline Variable & Dimension & $\begin{array}{c}\text { Numbers } \\
\text { of Items }\end{array}$ & $\begin{array}{c}\text { Cronbach's alpha Value } \geq \\
.70\end{array}$ \\
\hline \multirow{4}{*}{ UEM } & UEP & 4 & .832 \\
\cline { 2 - 4 } & OUE & 4 & .897 \\
\cline { 2 - 4 } & LUE & 4 & .734 \\
\cline { 2 - 4 } & SUE & 4 & .822 \\
\hline \multirow{3}{*}{ VD } & STRD & 6 & .767 \\
\cline { 2 - 4 } & RVT & 7 & .821 \\
\cline { 2 - 4 } & MVS & 6 & .797 \\
\hline
\end{tabular}

Table (10) Descriptive Statistics of the University Education Management $(\mathrm{n}=452)$

\begin{tabular}{|c|c|r|r|r|}
\hline Item & Mean & Std. Error & Std. Deviation & \multicolumn{1}{c|}{ Variance } \\
\hline UEP1 & 3.1018 & .04909 & 1.04374 & 1.089 \\
\hline UEP2 & 3.2765 & .05318 & 1.13054 & 1.278 \\
\hline UEP3 & 3.5398 & .05167 & 1.09856 & 1.207 \\
\hline UEP4 & 3.2124 & .05049 & 1.07337 & 1.152 \\
\hline
\end{tabular}




\begin{tabular}{|c|r|r|r|r|}
\hline OUE1 & 3.0642 & .04948 & 1.05202 & 1.107 \\
\hline OUE2 & 3.2367 & .05097 & 1.08371 & 1.174 \\
\hline OUE3 & 3.1527 & .05082 & 1.08043 & 1.167 \\
\hline OUE4 & 3.4978 & .05075 & 1.07892 & 1.164 \\
\hline LUE1 & 3.1018 & .05670 & 1.20542 & 1.453 \\
\hline LUE2 & 3.1637 & .05425 & 1.15331 & 1.330 \\
\hline LUE3 & 3.1571 & .05287 & 1.12406 & 1.264 \\
\hline LUE4 & 3.2323 & .05263 & 1.11888 & 1.252 \\
\hline SUE1 & 3.0575 & .05281 & 1.12274 & 1.261 \\
\hline SUE2 & 3.1217 & .05042 & 1.07203 & 1.149 \\
\hline SUE3 & 3.0730 & .04876 & 1.03657 & 1.074 \\
\hline SUE4 & 3.1681 & .05294 & 1.12542 & 1.267 \\
\hline Average & 3.197319 & 0.051739 & 1.099983 & 1.21175 \\
\hline
\end{tabular}

Table (11) Descriptive Statistics of the Vocational Development ( $\mathrm{n}=452)$

\begin{tabular}{|c|c|c|c|c|}
\hline Item & Mean & Std. Error & Std. Deviation & Variance \\
\hline STRD1 & 3.1615 & .05238 & 1.11352 & 1.240 \\
\hline STRD2 & 3.2765 & .05082 & 1.08040 & 1.167 \\
\hline STRD3 & 3.2013 & .05197 & 1.10500 & 1.221 \\
\hline STRD4 & 3.1903 & .05078 & 1.07958 & 1.165 \\
\hline STRD5 & 3.0841 & .05310 & 1.12894 & 1.275 \\
\hline STRD6 & 3.2190 & .05153 & 1.09556 & 1.200 \\
\hline RVD1 & 3.0442 & .05466 & 1.16215 & 1.351 \\
\hline RVD2 & 3.1460 & .05110 & 1.08646 & 1.180 \\
\hline RVD3 & 3.1549 & .05017 & 1.06669 & 1.138 \\
\hline RVD4 & 3.1128 & .05386 & 1.14497 & 1.311 \\
\hline RVD6 & 3.1416 & .05338 & 1.13495 & 1.288 \\
\hline MVS2 & 3.1173 & .05245 & 1.11509 & 1.243 \\
\hline MVS3 & 3.1903 & .05202 & 1.10596 & 1.223 \\
\hline MVS4 & 3.2279 & .05154 & 1.09578 & 1.201 \\
\hline MVS5 & 3.0310 & .05619 & 1.19456 & 1.427 \\
\hline Average & 3.153247 & 0.052397 & 1.113974 & 1.242 \\
\hline
\end{tabular}


Table (12) CFA estimates of the university education management, and vocational development

\begin{tabular}{|c|c|c|c|c|}
\hline Item & SRW & S.E. & C.R. & $\mathrm{P}$ \\
\hline UEP1 & .666 & .045 & 13.565 & *** \\
\hline UEP2 & .704 & .050 & 12.914 & *** \\
\hline UEP3 & .685 & .051 & 13.007 & **** \\
\hline UEP4 & .768 & .039 & 12.214 & **** \\
\hline OUE1 & .735 & .040 & 12.591 & **** \\
\hline OUE2 & .750 & .042 & 12.216 & **** \\
\hline OUE3 & .779 & .038 & 11.980 & $* * *$ \\
\hline OUE4 & .651 & .049 & 13.563 & $* * *$ \\
\hline LUE1 & .666 & .061 & 13.539 & $* * *$ \\
\hline LUE2 & .691 & .053 & 13.210 & $* * *$ \\
\hline LUE3 & .775 & .042 & 12.062 & $* * *$ \\
\hline LUE4 & .833 & .035 & 10.884 & $* * *$ \\
\hline SUE1 & .735 & .045 & 12.982 & $* * *$ \\
\hline SUE2 & .773 & .037 & 12.469 & $* * *$ \\
\hline SUE3 & .806 & .032 & 11.796 & *** \\
\hline SUE4 & .756 & .042 & 12.760 & *** \\
\hline STRD6 & .751 & .040 & 13.343 & $* * *$ \\
\hline STRD5 & .761 & .040 & 13.260 & $* * *$ \\
\hline STRD4 & .752 & .038 & 13.394 & $* * *$ \\
\hline STRD3 & .746 & .041 & 13.411 & $* * *$ \\
\hline STRD2 & .758 & .039 & 13.342 & $* * *$ \\
\hline STRD1 & .703 & .047 & 13.815 & $* * *$ \\
\hline RVD6 & .763 & .041 & 13.067 & *** \\
\hline RVD4 & .784 & .040 & 12.751 & **** \\
\hline RVD3 & .775 & .036 & 12.949 & $* * *$ \\
\hline RVD2 & .815 & .033 & 12.271 & $* * *$ \\
\hline RVD1 & .719 & .048 & 13.567 & $* * *$ \\
\hline MVS5 & .752 & .048 & 12.863 & $* * *$ \\
\hline M VS4 & .750 & .043 & 12.913 & **** \\
\hline M VS3 & .838 & .033 & 11.145 & **** \\
\hline MVS2 & .842 & .033 & 11.041 & *** \\
\hline
\end{tabular}

Table (13) Correlation Relationships in structural equation model of Exogenous Variable

\begin{tabular}{|l|l|l|r|r|l|l|}
\hline \multicolumn{3}{|c|}{ Path } & Correlation Coefficient & S.E. & C.R. & P \\
\hline VD & $<-->$ & UEM & .965 & .052 & 9.317 & $* * *$ \\
\hline
\end{tabular}

Table (14) Summary of Hypotheses Testing Result

\begin{tabular}{|l|l|l|}
\hline $\begin{array}{c}\text { No. of } \\
\text { Hypothesis }\end{array}$ & \multicolumn{1}{|c|}{ Hypothesis Statement } & Status \\
\hline H1 & $\begin{array}{l}\text { University education management has a significant and } \\
\text { positive related to vocational development. }\end{array}$ & Accepted \\
\hline H2 & $\begin{array}{l}\text { University education management has a significant and } \\
\text { positive effect on vocational development. }\end{array}$ & Accepted \\
\hline H3 & $\begin{array}{l}\text { There are significant differences between dependent variable } \\
\text { and independent variables. }\end{array}$ & Accepted \\
\hline
\end{tabular}

